\title{
Replacement of the First GnRH Administration in the Ovsynch Protocol by Selecting Cows According to the Stage of Follicular Development
}

\author{
P. HARTMAN, J. ZAJÍC, S. ČECH, Z. JAN, R. DOLEŽEL \\ University of Veterinary and Pharmaceutical Sciences Brno
}

Received July 26, 2005

Accepted December 12, 2005

\begin{abstract}
Hartman P., J. Zajíc, S. Čech, Z. Jan, R. Doležel: Replacement of the First GnRH Administration in the Ovsynch Protocol by Selecting Cows According to the Stage of Follicular Development. Acta Vet. Brno 2006, 75: 65-72.

The aim of the study was to replace the first GnRH in the Ovsynch protocol by selecting cows bearing corpus luteum as well as follicles in a defined stage of development at $\mathrm{PGF}_{2 \alpha}$ administration. Additionally, various terms of $\mathrm{GnRH}$ administration after $\mathrm{PGF}_{2 \alpha}$ were tested. Seventy five non-pregnant cows bearing corpus luteum were divided into groups according to the phase of follicular development on D 0 (day of $\mathrm{PGF}_{2 \alpha}$ administration) - growth (GR, follicles $3.0-7.9 \mathrm{~mm}$ in diameter), early dominance (ED, dominant follicle $8.0-14.9 \mathrm{~mm}$ ) and late dominance (LD, dominant follicle $15.0-23.0 \mathrm{~mm}$ ). In addition, the cows were divided into groups according to the terms of GnRH administration $\left(24,48\right.$ or $72 \mathrm{~h}$ after $\left.\mathrm{PGF}_{2 \alpha}\right)$. In this way, groups GR $48(\mathrm{n}=5)$, GR $72(\mathrm{n}=6)$, ED $24(\mathrm{n}=10)$, ED $48(\mathrm{n}=12)$, ED $72(\mathrm{n}=12), \operatorname{LD} 24(\mathrm{n}=10), \mathrm{LD}$ $48(\mathrm{n}=10)$ and LD $72(\mathrm{n}=10)$ were established. Growth of ovulatory follicle, term of ovulation, insemination and conception rates as well as relation of the size of preovulatory follicle (day of ovulation) to the size of following corpus luteum (day 14) were evaluated. The highest level of synchronization of ovulation ( $100 \%$ on D 3$)$ as well as conception rate (50\%) was achieved in group ED 48. This protocol gives an opportunity of timing artificial insemination to $18-24$ hours after $\mathrm{GnRH}$ administration, as ovulation occurs with a high probability within $24-48$ hours after GnRH administration.
\end{abstract}

Oestrus synchronization, follicle diameter, ovulation, timing of insemination

Synchronization of oestrus in cows with a standard term of ovulation provides a good opportunity for the timing of artificial insemination. It can decrease losses caused by poor oestrus detection and in addition, it can improve the embryo-transfer efficiency. The term of ovulation after administration of $\mathrm{PGF}_{2 \alpha}$ in the luteal phase of the oestrous cycle is variable because it depends on the stage of follicular development at the time of treatment (King et al. 1982; Macmillan and Henderson 1984; Kastelic et al. 1990; Savio et al. 1990; Kastelic and Ginther 1991). Follicular development can be synchronized by administration of $\mathrm{GnRH}$, followed by removal of the dominant follicle (ovulation or atresia) and recruitment of a new follicular wave (Thatcher et al. 1989; Macmillan and Thatcher 1991; Twagiramungu et al. 1995). This effect of GnRH is applied in the Ovsynch protocol (Pursley et al. 1995) as well as similar methods of oestrus synchronization in cows (Pursley et al. 1997; Pancarci et al. 2002; Thatcher et al. 2002). Nevertheless, the ovulation of a premature follicle after the first $\mathrm{GnRH}$ administration (Roy and Twagiramungu 1999; DeJarnette et al. 2001) and an incomplete luteal regression following $\mathrm{PGF}_{2 \alpha}$ (Burke et al. 1996; Moreira et al. 2000) are described. This is probably associated with the conception failure in the Ovsynch protocol (Kim et al. 2003). In our study we replaced the first GnRH in the Ovsynch protocol by selecting cows bearing corpus luteum as well as follicles in a defined stage of development at $\mathrm{PGF}_{2 \alpha}$ administration. In addition, the various terms of $\mathrm{GnRH}$ administration after $\mathrm{PGF}_{2 \alpha}$ were tested.

Address for correspondence:

Doc. MVDr. Radovan Doležel, CSc

Clinic of Diseases of Ruminants

University of Veterinary and Pharmaceutical Sciences

Palackého 1-3, 61242 Brno, Czech Republic

Phone: +420 541562316

E-mail: dolezelr@vfu.cz

http://www.vfu.cz/acta-vet/actavet.htm 


\section{Materials and Methods}

Experimental animals

Seventy five lactating cows (crossbreeds Bohemian Pied Cattle and Holstein) bearing corpora lutea (CLs) within 55 and 100 days post partum were used in our study. They were housed in three commercial dairy farms, and the average milk production of the herds was between 6500 and $8000 \mathrm{~kg}$ of milk per lactation. Conception rates after the first insemination in the herds were around $35-40 \%$ during the period of the study. The cows were divided into groups according to the phase of follicular development in the ultrasonographical image - growth (GR, follicles $3.0-7.9 \mathrm{~mm}$ in diameter, $\mathrm{n}=11$ ), early dominance (ED, dominant follicle $8.0-14.9 \mathrm{~mm}, \mathrm{n}=34$ ) and late dominance (LD, dominant follicle $15.0-23.0 \mathrm{~mm}, \mathrm{n}=30$ ). A follicle $\geq 8 \mathrm{~mm}$ in diameter at least $2.0 \mathrm{~mm}$ larger than the remaining ones was considered as the dominant follicle. The cows were treated by synthetic analog of $\mathrm{PGF}_{2 \alpha}$ cloprostenol (Oestrophan, Bioveta, Ivanovice, Czech Rep., $500 \mu \mathrm{g}$ pro toto, i.m.) and following administration of GnRH (lecirelinum, Supergestran, Ferring-Leciva, Jesenice, Czech Rep., $100 \mu \mathrm{g}$ pro toto, i.m.) were performed 24, 48 or $72 \mathrm{~h}$ after $\mathrm{PGF}_{2 \alpha}$. In addition, the cows were divided in groups according to the terms of GnRH administration. In this way groups GR $48(n=5), G R 72(n=6), \operatorname{ED} 24(n=10), \operatorname{ED} 48(n=12), \operatorname{ED} 72(n=$ 12), LD $24(\mathrm{n}=10), \operatorname{LD} 48(\mathrm{n}=10)$ and LD $72(\mathrm{n}=10)$ were established. Group GR 24 was not established because of a small number of cows bearing follicles in the growth phase of the follicular wave.

\section{Observation}

Transrectal ultrasonographical examinations (Aloca SSD 500 with a $5 \mathrm{MHz}$ rectal probe, Tokyo, Japan) of ovarian structures were performed daily from day 0 (day of $\mathrm{PGF}_{2 \alpha}$ administration) to day 5 and on day 14 . Ultrasonographical images of ovarian structures were taken by a digital video camera (Sony DCR-TRV 235 E) and data were compiled in the studio DV plus Pinnacle ${ }^{\circledR}$ system. Additional measurements of ovarian structures were made in Auto-CAD ${ }^{\mathbb{2}}$ 2002. Diameters of ovarian structures were determined as an arithmetical mean of two axes vertical to each other. Peripheral blood samples were obtained on days 0,2 and 14 . The blood was centrifuged and it was stored at $-20^{\circ} \mathrm{C}$ until progesterone determination by RIA, using commercial sets (Immunotech, Prague, Czech Republic). The detection of oestrus was performed by herd personnel twice a day and cows in oestrus were inseminated. Pregnancy diagnosis was performed ultrasonographically on day 25 and 39 after insemination (see Fig. 1). Disappearance of the dominant follicle followed by appearance of corpus luteum in the same place of the ovary on day 14 was considered as evidence of ovulation. Oestrus was considered as synchronized when ovulation appeared up to day 5 after $\mathrm{PGF}_{2 \alpha}$ administration.

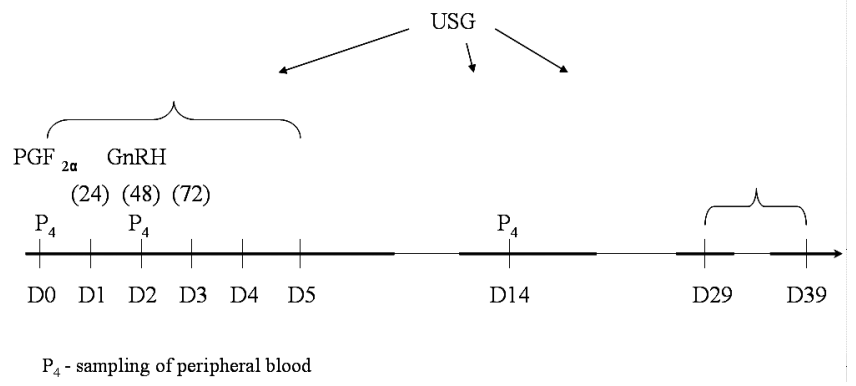

Fig. 1. Scheme of the study

\section{Evaluation}

Growth of the ovulatory follicle, the term of ovulation, insemination and conception rates as well as the relation of the size of the preovulatory follicle (day of ovulation) to the size of the following corpus luteum (day 14) were evaluated.

A comparison was made of follicle sizes within an individual group as well as among the groups, using parametric tests. Statistical analysis of ovulation occurrence on day 3 (day 0 - day of $\mathrm{PGF}_{2 \alpha}$ administration) was done on one hand among common groups divided according to the stage of follicular development at $\mathrm{PGF}_{2 \alpha}$ administration, regardless of the term of GnRH administration (groups GR, ED and LD); and on the other hand it was done among groups divided according to the term of GnRH administration, regardless of the stage of follicular development at $\mathrm{PGF}_{2 \alpha}$ administration (groups 24,48 and 72). Synchronizations of ovulation were evaluated using a Two-way table, which is available at the web site: http://caspar.bgsu.edu/ software/java/1Contingency.html. This table used Chi-square $\left(\chi^{2}\right)$ or G-tests $(\mathrm{G})$. Statistically significant deviation is evaluated by the Freeman-Tukey test which determines unexpected higher or lower values in the frame of a null hypothesis. Willam's correction was performed and all statistics were compared by the Chi-square distribution with appropriate degrees of freedom. The relationship of the sizes of preovulatory follicles to the sizes of corpora lutea was evaluated by Kruskal-Wallis or Steel-Dwass tests. 


\section{Results}

The growth of ovulatory follicles is shown in Tables 1, 2 and 3. Significant differences in follicle diameters were found between follicles on day of $\mathrm{PGF}_{2 \alpha}$ administration and follicles on day of GnRH administration in GR, LD $(p<0.05)$ as well as $\operatorname{ED}(p<0.01)$ groups. The differences were not proved between follicles on the day of $\mathrm{GnRH}$ administration and follicles on the day of ovulation. Even follicles became smaller in LD groups during this period.

Table 1. Means $( \pm$ SEM) of preovulatory follicle diameters in groups GR $48(\mathrm{n}=3)$ and GR $72(\mathrm{n}=1)(\mathrm{mm})$

\begin{tabular}{|l|l|l|l|l|l|l|}
\hline & D0 & D1 & D2 & D3 & D4 & D5 \\
\hline GR 48 & $5.73 \pm 0.72$ & $8.55 \pm 0.84$ & $10.23 \pm 1.81$ & $10.96 \pm 1.96$ & 0 & 0 \\
\hline GR 72 & 7.35 & 10.25 & 10.95 & 13.75 & 15.5 & 0 \\
\hline
\end{tabular}

Table 2. Means $( \pm$ SEM) of preovulatory follicle diameters in groups ED $24(n=9)$, ED $48(n=12)$ and ED $72(\mathrm{n}=8)(\mathrm{mm})$

\begin{tabular}{|l|l|l|l|l|l|c|}
\hline & D0 & D1 & D2 & D3 & D4 & D5 \\
\hline ED 24 & $11.28 \pm 2.35$ & $11.37 \pm 2.6$ & $12.3 \pm 2.81$ & 0 & 0 & 0 \\
\hline ED 48 & $10.45 \pm 2.87$ & $11.18 \pm 2.26$ & $12.76 \pm 2.16$ & $12.34 \pm 2.69$ & 0 & 0 \\
\hline ED 72 & $10.96 \pm 2.8$ & $11.26 \pm 4.11$ & $13.7 \pm 3.58$ & $15.2 \pm 2.04$ & $14.89 \pm 2.69$ & 0 \\
\hline
\end{tabular}

Table 3. Means $( \pm$ SEM) of preovulatory follicle diameters in groups LD $24(n=9)$, LD $48(n=5)$ and $\operatorname{LD} 72(\mathrm{n}=7)(\mathrm{mm})$

\begin{tabular}{|l|c|c|c|c|c|c|}
\hline & D0 & D1 & D2 & D3 & D4 & D5 \\
\hline LD 24 & $14.9 \pm 3.01$ & $15.18 \pm 2.68$ & $14.88 \pm 2.58$ & $12.78 \pm 1.53$ & 0 & 0 \\
\hline LD 48 & $16.46 \pm 1.64$ & $15.68 \pm 2.68$ & $14.90 \pm 3.29$ & $15.29 \pm 2.37$ & 0 & 0 \\
\hline LD 72 & $16.24 \pm 1.50$ & $16.98 \pm 1.85$ & $16.91 \pm 3.43$ & $17.37 \pm 2.22$ & $14.50 \pm 2.00$ & 0 \\
\hline
\end{tabular}

Ovulation was observed in $72 \%(54 / 75)$ of all experimental cows up to day 5 . Ovulations occurred on days 2, 3 and 4 . The highest incidence of ovulation was found on day 3 . For this reason we evaluated ovulations which occurred on day 3 . The highest level of synchronization of ovulation was found in group ED 48 in which $100 \%(12 / 12)$ cows ovulated on day 3 after $\mathrm{PGF}_{2 \alpha}$ administration on day 0 (Table 4).

Table 4. Occurrence of ovulation in all experimental groups up to day 5 after $\mathrm{PGF}_{2 \alpha}$ administration on day 0

\begin{tabular}{|l|c|c|ccc|ccc|}
\hline & \multicolumn{9}{|c|}{ Groups } \\
\hline \multirow{3}{*}{ Day } & \multicolumn{2}{|c|}{ GR } & \multicolumn{3}{c|}{ ED } & \multicolumn{3}{c|}{ LD } \\
\cline { 2 - 9 } & 48 & 72 & 24 & 48 & 72 & 24 & 48 & 72 \\
\cline { 2 - 9 } & $(\mathrm{n}=5)$ & $(\mathrm{n}=6)$ & $(\mathrm{n}=10)$ & $(\mathrm{n}=12)$ & $(\mathrm{n}=12)$ & $(\mathrm{n}=10)$ & $(\mathrm{n}=10)$ & $(\mathrm{n}=10)$ \\
\hline D2 & 0 & 0 & 9 & 0 & 1 & 7 & 0 & 0 \\
D3 & 3 & 0 & 0 & 12 & 3 & 2 & 4 & 6 \\
D4 & 0 & 1 & 0 & 0 & 4 & 0 & 1 & 1 \\
\hline D0- D5 & 3 & 1 & 9 & 12 & 8 & 9 & 5 & 7 \\
& $60 \%$ & $17 \%$ & $90 \%$ & $100 \%$ & $67 \%$ & $90 \%$ & $50 \%$ & $70 \%$ \\
\hline
\end{tabular}

In common groups divided according to the stage of follicular development at $\mathrm{PGF}_{2 \alpha}$ administration (regardless to term of $\mathrm{GnRH}$ administration) the highest occurrence of ovulation on day 3 (the $3^{\text {th }}$ day after $\mathrm{PGF}_{2 \alpha}$ administration) was found in group ED and the lowest occurrence was found in group GR $(p<0.01)$, see Fig. 2.

On the other hand, in common groups divided according to the term of $\mathrm{GnRH}$ 


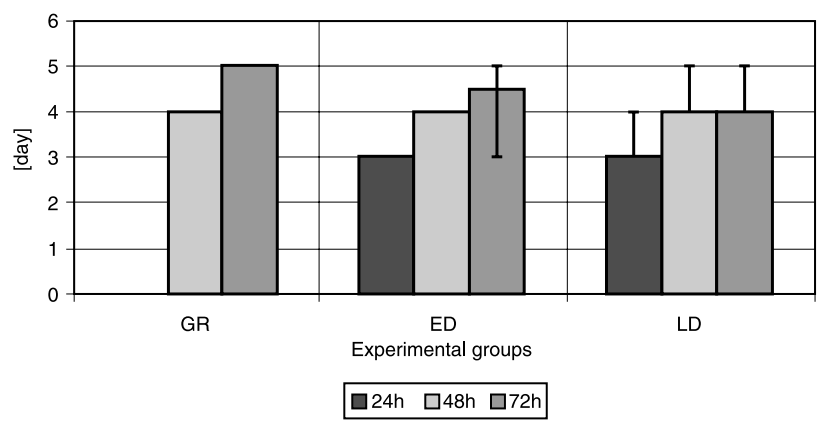

Fig. 2. Terms of ovulation in experimental groups $(24, n=18 ; 48, n=20,72, n=16)$ in relationship to phase of follicular development on D 0 (median, max.-min).

administration (regardless of the stage of follicular development at $\mathrm{PGF}_{2 \alpha}$ administration), the highest occurrence of ovulation on day 3 was found in group 72 and the lowest occurrence was found in group $24(p<0.05)$, see Fig. 3 .

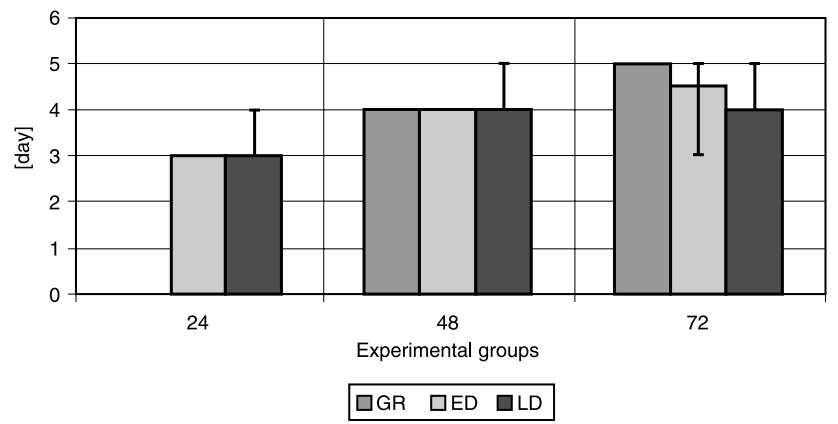

Fig. 3. Term of ovulation in experimental groups (GR, $n=4$; ED, $n=29, \mathrm{LD}, \mathrm{n}=21$ ) in relationship to term of administration $\mathrm{GnRH}$ (median, max.-min).

The highest occurrence of ovulation, within 5 days after $\mathrm{PGF}_{2 \alpha}$ administration, was found in group $48(p<0.001)$.

Insemination was done in $45 \%(34 / 75)$ experimental cows and the average pregnancy rate was only $24 \%$. The highest conception rate $(50 \%)$ was found in group ED 48 . Positive correlations were found between sizes of preovulary follicles on the day of ovulation and sizes of corpora lutea on day 14 in groups ED 24, ED 48, ED 72, LD 24 and LD 72 $(p<0.001)$ as well as in groups GR 48 and LD $48(p<0.01)$. Group GR 72 could not be evaluated for a small number of evaluated cows.

\section{Discussion}

We could not establish complete groups of cows bearing only small follicles $(3.0-7.9$ $\mathrm{mm}$ in diameter) on ovaries. Low incidence of these cows was probably caused by frequent persistence of a morphologically dominant follicle during the growth phase of a new follicular wave. Persistence of morphological dominance after the loss of functional dominance in follicles during follicular waves in cows has been described (Fortune 1993; Savio et al. 1990). For that reason the growth phase of a follicular wave cannot be exactly differentiated from late dominance in cows on the basis of ultrasonographical examination. 
Thus some cows bearing a follicle $15.0-23.0 \mathrm{~mm}$ in diameter could be in fact in the growth phase of a new follicular wave in our study. There is a chance to induce a growth phase of a new follicular wave artificially, by puncturing follicles under ultrasonographical guidance (the ovum pick up method - OPU). However, we did not use it, as the OPU may negatively influence the next oestrous cycle. Smaller corpora lutea with lower progesterone concentrations in peripheral blood and a low conception rate after OPU were described (Vasconcelos et al. 2001).

We found high growth potency of ovulatory follicles after $\mathrm{PGF}_{2 \alpha}$ up to $\mathrm{GnRH}$ administration in all experimental groups. Low growth potency after GnRH up to ovulation especially in groups LD is partly in agreement with authors DiZerega and Hodgen (1980) who found in cows treated by GnRH an outstandingly higher growth potency of small growing follicles before selection, compared to large dominant follicles. Reduction of size in some preovulatory follicles can be caused by a decrease of follicle tension after a temporal decrease of FSH concentration (Ginther 2000).

The term of ovulation after single administration of $\mathrm{PGF}_{2 \alpha}$ in cows bearing corpus luteum is variable, because it depends on the stage of follicular development at the time of treatment (Macmillan and Henderson 1984; Savio et al. 1990; Kastelic et al. 1990; Turzillo and Fortune 1993). The highest dispersion of ovulation after $\mathrm{PGF}_{2 \alpha}$ was described when treatment was performed in the middle of the oestrous cycle (Tanabe and Hann 1984). Nevertheless, most cows ovulate on day 3 after treatment (Stellflung et al. 1975; Král et al. 1981; Larson and Ball 1992). In our study, $72 \%$ of cows ovulated up to day 5 after $\mathrm{PGF}_{2 \alpha}$ administration regardless of the stage of follicular development at $\mathrm{PGF}_{2 \alpha}$ treatment as well as the term of $\mathrm{GnRH}$ administration. In agreement with the above stated authors, most cows (55.6\%) ovulated on day 3 after treatment. The highest level of synchronization of ovulation after $\mathrm{PGF}_{2 \alpha}$ was found when treatment was performed on cows bearing corpus luteum as well as an early dominant follicle, and GnRH was administered 48 hours after $\mathrm{PGF}_{2 \alpha}$ (group ED 48). Ovulation occurred in $100 \%$ of these cows on day 3 after $\mathrm{PGF}_{2 \alpha}$ treatment.

Although a relatively standard occurrence of ovulation after $\mathrm{PGF}_{2 \alpha}$ treatment was found in our study, a few cows (45\%) were inseminated and the total conception rate was very low $(24 \%)$. Ten cows were inseminated despite ovulation not having occurred. On the other hand, 30 cows were not inseminated despite ovulation having occurred. These data show low efficiency of oestrus detection in the herds. A poor rate of oestrus detection in herds of milk cows is also described by many other authors (Noakes et al. 2001; Arney et al. 1994; Kerbrat a Disenhaus 2004). The authors mention the level of incorrect detection around $61 \%$. An especially low rate of oestrus detection was found after $\mathrm{PGF}_{2 \alpha}$ treatment (Slenning and Farver 1990). For this reason, the low conception rate was partly caused by poor oestrus detection allowing insemination of unovulatory cows in our study. On the basis of these data, a higher conception rate after insemination could be expected regardless of oestrus detection. A low conception rate is often associated with abnormal corpus luteum with short and low production of progesterone after insemination (R o s en berg et al. 1990; Gy awu et al. 1991; Morell et al. 1991; Xu et al. 1997). Nevertheless, the quality of corpus luteum depends on the quality of the preovulatory follicle (S mith 1986; Vasconcelos et al. 2001). Likewise, the length as well as the level of higher concentration of progesterone before ovulation influences the quality of preovulatory follicles as well as the quality of the subsequent corpus luteum (White et al. 1985; Smith 1986; Vasconcelos et al. 2001). For this reason low conception rate could be partly caused by the short luteal phase before ovulation in our study. Generally, environmental factors significantly influence the conception rate. But the conception rate after the first insemination in the herds involved in the study was higher $(35-40 \%)$ at the time of the experiment. These data show that a low 
conception rate is probably not caused by environmental conditions. Frequent manipulation with uterus and ovaries within the transrectal ultrasonographical examination could negatively influence conception, too. Roelofs et al. (2004) reported that frequent ultrasonographical examination did not have a negative effect on oestrus behaviour nor the rate of oestrus detection. But higher variability of the term of ovulation was noted. Nevertheless, the relatively high conception rate (50\%) in group ED 48 shows that the main factors influencing conception rate in our study are probably the protocol of hormonal treatment as well as the quality of ovarian structures. Lower conception rate $(31.1 \%)$ was found after the Ovsynch protocol (Peters and Pursley 2003).

Our results show that $\mathrm{PGF}_{2 \alpha}$ treatment in cows bearing corpus luteum as well as the early dominant follicle with following administration of $\mathrm{GnRH} 48$ hours after $\mathrm{PGF}_{2 \alpha}$ represents an efficient protocol of oestrus synchronization. This protocol gives an opportunity for timing artificial insemination to $18-24$ hours after $\mathrm{GnRH}$ administration because ovulation occurs with a high probability within 24 - 48 hours after GnRH administration.

\section{Nahrazení první aplikace GnRH v Ovsynch metodě výběrem krav podle fáze folikulárního vývoje}

Cílem studie bylo nahradit první aplikaci GnRH v Ovsynch metodě synchronizace ř́je výběrem krav se žlutým tělískem a folikuly v definovaném stádiu vývoje př́i aplikaci $\mathrm{PGF}_{2 \alpha}$. Navíc byl testován různý termín následné aplikace GnRH. Sedmdesát pět jalových krav vykazujících žluté tělísko bylo rozděleno do skupin podle stádia folikulárního vývoje v D 0 (den aplikace $\mathrm{PGF}_{2 \alpha}$ ) na skupiny - růstu (GR, folikuly 3,0 - 7,9 $\mathrm{mm}$ v průměru), časné dominance (ED, dominantní folikul $8,0-14,9 \mathrm{~mm}$ ) a pozdní dominance (LD, dominantní folikul 15,0 - 23,0 mm). Následně byly skupiny rozděleny podle doby aplikace GnRH (24, 48 nebo 72 hodin po $\mathrm{PGF}_{2 \alpha}$. Tímto způsobem byly vytvořeny skupiny GR $48(\mathrm{n}=5), \mathrm{GR} 72$ $(n=6)$, ED $24(n=10)$, ED $48(n=12)$, ED $72(n=12)$, LD $24(n=10)$, LD $48(n=10)$ a LD $72(\mathrm{n}=10)$. Ultrasonografické vyšetření bylo prováděno denně od D 0 do D 5 a v D 14 a vzorky periferní krve ke stanovení progesteronu RIA metodou byly odebírány v D 0, D 2 a D 14. Ríjící se krávy byly inseminovány. Nejvyšší úroveň synchronizace ovulace byla zaznamenána ve skupině ED 48, kde ovulovalo 100 \% (12/12) krav v D 3. Rovněž nejvyšší úroveň zabřezávání (50 \%) byla zjištěna v této skupině. Výsledky naší studie ukazují, že aplikace PGF $_{2 \alpha}$ u krav vykazujících žluté tělísko a časně dominantní folikul s následnou aplikací GnRH 48 hodin po $\mathrm{PGF}_{2 \alpha}$ představuje účinnou metodu synchronizace ř́je. Uvedený postup umožňuje časování inseminace na interval 18 - 24 hodin po aplikaci GnRH, poněvadž ovulaci lze s velkou pravděpodobností očekávat v intervalu 24 - 48 hodin po aplikaci GnRH.

\section{Acknowledgements}

This study was supported by grant SMS 6215712403. We thank dairy farmers (Agrodružstvo Brtov-Lipůvka, AGRIA, a. s. Nížkovice and GENAGRO Ríčany) which made research possible on their farms. In addition we thank Dr. M. Vyskočil, PhD. for statistical analysis.

\section{References}

ARNEY DR, KITWOOD SE, PHILIPS CJC 1994: The increase in activity during oestrus in dairy cows. Appl Anim Behav Sci. 40: 211-218

BURKE JM, SAL SOTA RL, DE LA RISCO CA, STAPLES CR, SCHMITT EJ, THATCHER WW 1996: Evaluation of timed insemination using a gonadotropin-releasing hormone agonist in lactating dairy cows. J Dairy Sci 79: 1385-1393

DEJARNETTE JM, SALVERSON RR, MARSHALL CE 2001: Incidence of premature estrus in lactating cows and conception Mates to standing estrus or fixed-time inseminations after synchronization usány GnRH and PGF $_{2 \alpha}$. Anim Reprod Sci 67: 27-35

DI ZEREGA GS, HODGEN GD 1980: The primate ovarian cycle: suppression of human menopausal gonadotropin-induced follicular growth in the presence of the dominant follicle. J Clin Endocrinol Metabol 50: $819-825$ 
FORTUNE JE 1993: Follicular dynamics during the bovine estrous cycle: A limiting factor in improvement of fertility? Anim Reprod Sci 33: 111-125

GINTHER OJ 2000: Selection of the dominant follicle in cattle and horses. Anim Reprod Sci: 60/61: 61-79

GYAWU P, DUCKER MJ, POPE GS, SAUNDERS RW, WILSON GDA 1991: The value of progesterone, oestradiol benzoate and cloprostenol in controlling the timing of oestrus in dairy cows and allowing successful fixed-time insemination. Br Vet J 147: 171-182

KASTELIC JP, GINTHER OJ 1991: Factors affecting the origin of the ovulatory follicle in heifers with induced luteolysis. Anim Reprod Sci 26: 13-24

KASTELIC JP, KNOPF L, GINTER OJ 1990: Effect of day of prostaglandin $\mathrm{F}_{2 \alpha}$ treatment on selection and development of the follicle in heifers. Anim Reprod Sci 23: 169-180

KERBRAT S, DISENHAUS C. 2004: A proposition for an updated behavioural characterization of the oestrus period in dairy cows. Appl Anim Behav Sci 87: 223-238

KIM IH, SUH GH, SON DS 2003: A progesterone-based timed AI protocol more effectively prevents premature estrus and incomplete luteal regression than an Ovsynch protocol in lactating Holstein cows. Theriogenology 60: $809-817$

KING ME, KIRACOFE GH, STEVENSON JS, SCHALLES RR 1982: Effect of stage of the estrous cycle on interval to estrus after $\mathrm{PGF}_{2 \alpha}$ in beef cattle. Theriogenology 18: 191-200

KRÁL J, BÍLEK P, ORTELOVÁ J, DVOŘAK M, ROUTA V, ŠEVČÍK B 1981: Sledování biologické účinnosti Oestrophanu inj. (Spofa) na jalovicích. Biol Chem Vet 17: 17-27

LARSON LL, BALL PJH 1992: Regulation of estrous cycles in dairy cattle: a review. Theriogenology 38: 255-267

MACMILLAN KL, HENDERSON HV 1984: Analyses of the variation in the interval from an injection of prostaglandin $\mathrm{F}_{2 \alpha}$ to oestrus as a method of studying patterns of follicle development during dioestrus in dairy cows. Anim Reprod Sci 6: 245-254

MACMILLAN KL, THATCHER WW 1991: Effects of an agonist of gonadotropin-releasing hormone on ovarian follicles in cattle. Biol Reprod 45: 883-889

MOREIRA F, DE LA SOTA RL, DIAZ T, THATCHER WW 2000: Effect of day of the estrous cycle at the initiation of a timed artificial insemination protocol on reproductive responses in dairy heifers. J Anim Sci 78: $1568-1576$

MORRELL JM, NOAKES DE, ZINTZARAS E, DRESSER DW 1991: Apparent decline in fertility in heifers after repeated estrus synchronization with cloprostenol. Vet Rec 128: 404-407

NOAKES DE, PARKINSON TJ, ENGLAND GCW 2001: Artur's Veterinary Reproduction and Obstetrics $\left(8^{\text {th }}\right.$ ed.). W. B. Saunders, London.

PANCARCI SM, JORDAN ER, RISCO CA, SCHOUTEN MJ, LOPEZ FL, MOREIRA F, THATCHER WW 2002: Use of estradiol cypionate in a presynchronized timed artificial insemination program for lactating dairy cattle. J Dairy Sci 85: 122-131

PETERS MW, PURSLEY JR 2003: Timing of final GnRH of the Ovsynch protocol affects ovulatory follicle size, subsequent luteal function, and fertility in dairy cows. Theriogenology 60: 1197-1204

PURSLEY JR, MEE MO, WILTBANK MC 1995: Synchronization of ovulation in dairy cows using PGF $2 \alpha$ and GnRH. Theriogenology 44: 915-923

PURSLEY JR, WILTBANK MC, STEVENSON JS, OTTOBRE JS, GAVERICK HA, ANDERSON LL 1997: Pregnancy rates per artificial insemination for cows and heifers inseminated at a synchronized ovulation or synchronized estrus. J Dairy Sci 80: 295-300

ROELOFS JB, BOUWMAN EG, DIELEMAN SJ, VAN EERDENBURG FJCM, KAAL-LANSBERGEN LMTE, SOEDE NM, KEMP B 2004: Influence of repeated rectal ultrasound examinations on hormone profiles and behaviour around oestrus and ovulation in dairy cattle. Theriogenology 62: 1337-1352

ROSENBERG M, KAIM M, HERZ Z, FOLMAN Y 1990: Comparison of methods for the synchronization of estrous cycles in dairy cows. 1. Effects on plasma progesterone and manifestation of estrus. J Dairy Sci 73: 2807-2816

ROY GL, TWAGIRAMUNGU H 1999: Time interval between GnRH and prostaglandin injections influences the precision of estrus in synchronized cattle. Theriogenology 51: $413 \mathrm{p}$.

SAVIO JD, BOLAND MP, HYNES N, MATTIACCI MR, ROCHE JF 1990: Will the first dominant follicle of the estrous cycle of heifers ovulate following luteolysis on day 7? Theriogenology 33: 677-387

SLENNING BD, FARVER TB 1990: Oestrus detection efficiency and the effects of using prostaglandin F2 in a commercial dairy herd. Prev Vet Med 8: 269-282

SMITH MF 1986: Recent advances in corpus luteum physiology. J Dairy Sci 69: 911-926

STELLFLUG JN, HAFS HD, LUUIS TM, SEGUIN BE 1975: Luteolysis, estrus and ovulation, and blood prostaglandin $\mathrm{F}$ after intramuscular administration of 15, 30 or $60 \mathrm{mg}$ prostaglandin F2alpha. Prostaglandins 9: 609-615

TANABE TY, HANN RC 1984: Synchronized estrus and subsequent conception in dairy cattle heifers treated with prostaglandin F $2 \alpha 1$. Influence of stage of cycle at treatment. J Anim Sci 58: 805-811

THATCHER WW, MACMILLAN KL, HANSEN PJ, DROST M 1989: Concepts for regulation of corpus luteum function by the conceptus and ovarian follicles to improve fertility. Theriogenology 31: 1-282 
THATCHER WW, MOREIRA F, PANCARCI SM, BARTOLOME JA, SANTOS JEP 2002: Strategies to optimize reproductive efficiency by regulation of ovarian function. Domestic Animal Endocrinology 23: 243-254

TURZILLO AM, FORTUNE JE 1993: Effects of suppressing plasma FSH on ovarian follicular dominance in cattle. J Reprod Fert 98: 113-119

VASCONCELOS JL, SARTORI R, OLIVEIRA HN, GUENTHER JG, WILTBANK MC 2001: Reduction in size of the ovulatory follicle reduces subsequent luteal size and pregnancy rate. Theriogenology 56: 307-314

WHITE LM, KEISLER DH, DAILEY RA, INSKEEP EK 1985: Characterization of preovulatory follicle destined to form ,subfunctional“ corpora lutea. Biol Reprod 32 (Suppl. 1): 43-56

XU ZZ, BURTON LJ, MACMILLAN KJ 1997: Reproductive performance of lactating dairy cows following estrus synchronization regimes with $\mathrm{PGF}_{2 \alpha}$ and progesterone. Theriogenology 47: 687-701 